\title{
Facing the Uncanny: Questioning Art with E. Levinas
}

\author{
JOLANTA SALDUKAITYTÉ \\ Department of Philosophy and Cultural Studies, Vilnius Gediminas Technical University, 1 Trakų Street, 01132 Vilnius \\ Email: Jolanta.saldukaityte@vgtu.lt
}

\begin{abstract}
The article peruses the idea that art, and more specifically, representation of the face, has something monstrous and uncanny in it. The author concentrates on Levinas's philosophy and shows that, first, art by giving the image to the face, freezes it in a plastic form and by this means turns it inevitably into a caricature. Second, face in art, unlike alive face, lacks temporality. What is lively, what is human expression is locked, not able to change, not exposed to vulnerability and therefore no longer is an ethical face of the Other. The article argues that Levinas does not reject the art but tries to re-locate it in a larger context of world: its meaning comes from being engaged in the word: social, cultural, political and above all ethical context.
\end{abstract}

Keywords: art, face, uncanny, ethics, Levinas

\section{INTRODUCTION: PASSAGEWAY TO ART OF UNCANNY}

We can find plenty of art which creates monsters (i.e. visualizes them): centaurs, gorgons, devils, demons, or Friedrich Wilhelm Murnau's Nosferatu, Bram Stoker's Dracula, Mary Shelley's Frankenstein's monster, Francisco Goya Saturn Devouring His Son, the Basilisk described by Pliny the Elder (23-79AD), and later continuing its existence in the cellars of Vilnius, Hieronymus Bosch monsters in the Garden of Earthly Delights, depictions of various medieval tortures and monstrosity in the Vic Episcopal Museum (Museu Episcopal de Vic - MEV) in Catalonia, etc. The list could go on and on. ${ }^{1}$ Although monstrosity, first of all, is described by physical characteristics, by impossible unnatural mixes of features and abilities, monsters are usually (sometimes falsely) connected with ugliness and evil. ${ }^{2}$ Another way to talk about monstrosity would be to raise the question of the human monster. In the latter case it usually refers not only to some jarring physical features but to pure evil, to the sort of act or intent which cannot be understood or justified in any way. We encounter such characters in Greek myth: Antigone, for example, does not belong in a 'normal' way to that polis, is weird and even monstrous for being her brother's daughter and her father's sister, and her mother's granddaughter. She is cursed by birth. As well she bears radical otherness shown by her not obeying the rules, the law, and exposing herself to the likelihood of death. For Martin Heidegger she was the uncanny character

1 More about it: Eco 2007; Baltrušaitis 1955; Asma 2009; Kearney 2003; Beal 2002.

2 In a broader sense it could be connected with the fear of strangeness and otherness as such which even up to now reveals itself in hate, in antisemitism, racism and the like. 
par excellence. Moral monsters, as, for example, indicated by Michel Foucault's studies on abnormalities, bend all the rules and abuse morality. Unlike monsters mentioned above, they might not have any monstrous perceivable features and from all externals be rather 'banal.'

All these depictions of monsters try to represent what in its essence is not representable. In other words, they try to understand and to show, to demonstrate what is essentially hidden, what lies at the bottom of our fears, anxieties, insecurity, and yet remains elusive. ${ }^{4}$ In this essay I am going to ask if and why art, representation of the face, can be monstrous or uncanny even if it does not depict any evident signs of such, without monstrous animals or people, and even without a macabre backstory.

Uncanniness has been addressed by many thinkers within different contexts: in psychology by Ernst Jentsch and Sigmund Freud; in mythology by F. W. J. Schelling; in philosophy by Martin Heidegger; in literature revealed by Edgard Allan Poe or Howard Phillips Lovecraft, among others; and, of course, in various movies. ${ }^{3}$ Sigmund Freud in his famous essay, The Uncanny (1919), suggests that 'the uncanny is that class of the frightening which leads back to what is known of old and long familiar' (Freud 1955: 220). In other words, he suggests that in some circumstances the familiar becomes strange, uncanny and frightening. For Freud, unlike for Jentsche, being novel and unfamiliar is not enough to be uncanny. It concerns not the new or foreign as such, but something familiar and old which has become estranged. Freud agrees with Schelling that 'everything is unheimlich that ought to have remained secret and hidden but has come to light' (Freud 1955: 225). In this sense, art could be understood as the process of turning what is strange into the familiar and what is familiar into the strange, at once something hiding and something revealing. But defamiliarization or estrangement of art is not necessarily only creating and bringing out various monsters and anxieties. Rather, art as such might be seen as a locus of the uncanny, or monstrous, as having 'an aura' of uncanny.

Even though at first sight Emmanuel Levinas may not look like the best interlocutor for these questions as he is, above all, a thinker of ethics and did not propose his philosophy as an aesthetic theory as such, he nonetheless refers to or uses example of art quite often. Various references to painting, sculpture, literature and music appear in all Levinas books, but probably are nowhere treated in more detail and depth than in the articles 'Reality and its Shadow' (1948), 'The Transcendence of Words: On Michel Leiris's Biffure' (1949), 'On Maurice Blanchot' (1975) and in the collection of articles Proper Names (1976).

Levinas's approach to art has been discussed extensively in the secondary literature and has in most cases concluded that Levinas is hostile to art, that art is idolatrous and brings us further from ethical responsibility, that it has no ethical dimension, or if so, then only evil, and therefore has no real or positive meaning in Levinas's ethical metaphysics. ${ }^{6} \mathrm{He}$, it is said, finds art to hide or even substitute images for the face of the other. Levinas several times mentions in his texts that art has something exotic, something monstrous and inhuman in it. In addition, the question of the uncanny naturally leads to the question of alterity and strangeness. With this in mind, I will address the question of the uncanniness of art in Levinas's philosophy.

\section{IMPOSSIBILITY OF THE FACE}

To the full extent, an ambiguity of art appears in its relation to the face. Levinas in his early article 'Is Ontology Fundamental' (1951) (Levinas 1996: 10) and later in Difficult Freedom (1963) (Levinas 1990: 8) wonders if things have faces. It does not need repeating the importance of

\footnotetext{
3 See Ellison 2001.
} 
the face, the human face, in Levinas's thought. In the secondary literature interpretations vary from trying to describe the face as concrete or as abstract. Levinas himself makes clear that face is not a plastic form, that the face exceeds its perceptible manifestation: 'it is not the mere assemblage of a nose, a forehead, eyes' (Levinas 1990: 8). Face reduced to its plastic form turns a person into an object, puts upon the face a mask, permits classification and therefore discrimination and uniformity. Face as expression exceeds the form of the face and in this sense is abstract. 'In the concreteness of the world, the face is abstract', says Levinas (Levinas 2003: 32). It breaks from any context. But it would be a mistake as well to consider that because the face is abstract it is no-one's face and cannot be distinguished or recognized as a particular person's distinctive face. Despite being abstract, the face for Levinas is also concrete. That might seem to be a puzzling idea, but we have to keep in mind the importance valence of body, of vulnerability, and, above all, of suffering. The face is concrete not only as a particular object, an object which can be destroyed, but as a particular vulnerability, his/her suffering, the singularized expression 'do not kill'. In other words, even if face is not a plastic image and radical alterity cannot be reduced to the materiality of things, the materiality of a face, the vulnerability of the other, requires us to meet the other as belonging to some race, some gender, of same age, and so on. In the materiality of face, in the body are inscribed particular social-cultural significations even if in no way can the otherness of the other be reduced to such significations. While the face of the Other is abstract, at the same time it is the most concrete, the most particular. So when Levinas says that idea of infinity is encountered in the face of the other, it does not indicate that face is an eidos, purified from all concreteness, materiality, and corporality. The face of the other surpasses the plastic image, is better, demands more.

Art, on the other hand, gives image to the face, freezes it in a plastic form in a picture, a portrait, a vase, etc., and by this means turns it inevitably into a caricature. Thus the face of the other person lies between holiness and caricature, abstract and concrete, is singular and calls forth my singularity, while art imprisons the face (Levinas 2007: 198). Art's plastic form is apparition, 'is always already deserted, betrayed, by the being it reveals, such as marble from which the gods it manifests already absent themselves' (Levinas 1987: 55). The Face, in contrast, is expression, mobile, alive. The alterity of the other is encountered in the face, the vulnerable and naked face which breaks its form. Art, sculpture, on the other hand, however mysterious, cannot retain the interiority of the face. Art objects hide in their own world or behind the form: 'Beauty, perfect form, is form par excellence; the statues of antiquity are never really naked' (Levinas 2001: 40).

Meaning comes from transcendence, from irreducible otherness of the other, but only and always as deriving from concrete situations. The other - 'abstract' in breaking from its context but at the same time absolutely singular, and hence absolutely concrete. The other person is the one who faces, in flesh and blood, this face, You. We must underline, then, that the otherness of the other, while concrete and singular, is not a function of weirdness, peculiarity, a tic, a pimple, skin color, and the like. 'The orphan, the widow, the stranger' might be a metaphor, but it is not only a metaphor. It refers as well to the concrete flesh and blood wandering stranger who is likely to be more in need than my neighbour who is at home. What matters, the alterity that exerts its pressure, as it were, is the other's vulnerability and need for help. 'Face as the very mortality of the other man' (Levinas 1998: 186). What singularizes both the other and myself is moral exigency: the other person as concrete materiality, vulnerable body, and I, and I alone, am the one who must provide. So the face, while being concrete, this or that face, is 'abstract' inasmuch as it is more, a surplus over its own genus and species, its relative differences. 
Things, on the other hand, have no faces: '[t]hey are beings without a face' (Levinas 1990: 8). But they have no face not because they are not abstract enough but because they are not concrete enough, or one might say both, correctly understood. The materiality of the things lies 'in the primacy of the Neuter' (Levinas 2007: 298) but not in sensibility and vulnerability. In other words, things are interchangeable, regardless of their particularity, as monetization shows; they do not have singularity, their alterity refers to dissolution in the elemental. A thing, Levinas says, 'can never be presented personally and ultimately has no identity' (Levinas 1990: 8). Cohen, in his book Levinasian Meditations, underlines that face to face encounter is an encounter of two singular beings: 'first, the singularity of the other person who as a mortal being of flesh and blood suffers and commands aid' and 'second, the singularity of the mortal subject who responds in a responsibility beholden to the face of the other' (Cohen 2010: 237). Singularity of the face and particularity or uniqueness of art, or thing, are not the same: ' $\mathrm{t}$ ] he singularity or face of the other person, unlike that of the thing, far from being a unique node within a differential system is rather an explosion of context, an excessive "nudity" (Cohen 2010: 243). The Face demands meeting the Other personally while such an encounter with things is impossible:

'Through the face, the being is not only enclosed in its form and offered to the hand, it is also open, establishing itself in depth and, in this opening, presenting itself somehow in a personal way. The face is an irreducible mode in which being can present itself in its identity. A thing can never be presented personally and ultimately has no identity. Violence is applied to the thing, it seizes and disposes of the thing. Things give, they do not offer a face' (Levinas 1990: 8).

So from considerations such as these it looks obvious that things do not and cannot have face: they do not suffer, do not die, they do not ask for help. To have a face, to encounter the face, means to be in the realm of ethics, to be vulnerable.

\section{ETERNITY OF THE INSTANT}

Western artists have all along been trying to catch expressivity: from the archaic smiles of korai to the suffering of Laocoon, the ecstasy of St. Therese, Mona Lisa's smile, from the self-reflecting look of Sapho to Munch's Scream. Calm and collected Michelangelo's David. Intense and bursting Bernini's David. To catch, to represent, to show expressions became one of the most important goals of art. It remains unchanged - the viewers might age, but Botticelli's Venus will always be just born.

Unlike the platonic shadow of reality, art remains unchanged, frozen within the stability of its form. But that is also exactly what bothers Levinas: in the best examples, it carves out the crystal of existence, a moment of life, but in itself a closed realm of meaning. It does not change, and we do not want it to, but as such it is not life but 'still life.' We know that the Greekbronze Poseidon (or Zeus) will never throw his trident, that Bernini's Persephone will never scream. Michelangelo Moses will always be just about to stand up. ${ }^{4}$ They are frozen in time and

4 Freud in his essay on Michelangelo Moses proposes that the sculpture should be seen as a part of a group 'and we cannot imagine that the figure was meant to arouse an expectation in the spectator, that it was on the point of leaping up from its seat and rushing away to create a disturbance on its own account' (Freud 1997: 131). Freud argues that more important is that this sculpture represented something which does not change and 'this Moses would remain sitting like this in his wrath forever' (Freud 1997: 132). It is interesting that Freud did not remark that even if a sculpture looks like it is about to move and refers to change rather than stability (like Egyptian sculptures), it nonetheless still remains frozen forever. 
the future will never come for them. That is why Levinas says that 'every artwork is in the statue - a stoppage of time' (Levinas 1989: 137). In this sense a 'statue's existing is a semblance of the existing of being' (Levinas 1989: 138). As such, even if it tries to overcome stability, wants to be lifelike, it fails and represents ontological being: being without event, without adventure. Art, like knowledge, like ontology is striving for the eternal but, according to Levinas, 'differs radically from the eternity of a concept' (Levinas 1989: 141). A concept does not have duration while instances of art in some manner - even if frozen - do. What is lively, what is human expression is locked, captured in the plasticity of form. No doubt this is the most uncanny and monstrous side of representational art. 'Whereas a phenomenon is already, in whatever respect, an image, a captive manifestation of its plastic and mute form, the epiphany of a face is alive' (Levinas 1989: 141). That, I suggest, is revealed in the short story Oval Portrait by Edgar Allan Poe. In Poe's story the narrator while staying in a chateau sees the painting of a young woman. He is so stricken by it that at first he closes his eyes. 'I had found the spell of the picture in an absolute life-likeliness of expression' (Poe 2016). The narrator discovers that the painter was painting his wife and all the love and admiration of the painter for his wife passed into her portrait. With his last brush stroke he finally achieved what he was trying for: 'This is indeed Life itself!' (Poe 2016). But when the liveness passed to the painting, his wife died. In his essay on the uncanny Freud reminds us that usually 'it is in the highest degree uncanny when inanimate objects - a picture or a doll - come to life' (Freud 1955: 246). ${ }^{5}$ Art work is in-between: it is scary, uncanny because it is connected to life, but it is not a life. It is 'a caricature of life', 'lifeless life' as 'the life of an artwork does not go beyond the limit of an instant' (Levinas 1989: 138) and has no power or control over its own 'life'. And, Levinas says, 'here too we should compare art with dreams: the instant of a statue is a nightmare' (Levinas 1989: 139).

Of course, the imitation theory of art does not exhaust the functions of art, which strives to more and more expressivity or closer proximity to a concept (conceptual art), but bothers Levinas that art is always trapped in the 'meanwhile.' A moment of time taken out of time. Meanwhile, it is the stillness and lifelessness of art. For this reason Levinas finds in art 'something inhuman and monstrous' (Levinas 1989: 141).

In discussing art and face in art the dimension of time is of utmost importance. We have already noted the non-plasticity of the face, which commentators usually bring into their argument regarding idolatry and image. The claim that Levinas sees art as idolatry and that he is merely prolonging a Jewish ban is quite common, and perhaps the most frequent criticism in the secondary literature. Nonetheless, it is all too easy, and in fact quite a misleading reading as it does not address either the specific nature or the value of art. It is an approach inadequate to grasp the specific difference of art, or differences between various arts. It rather obscures such differences, especially inasmuch as art too might try to overcome plasticity and only some but not all art seeks expressivity. In order to grasp the essence of art, as Cohen makes clear in Elevations and in ...Getting 'Reality and Its Shadow' Right, we have to look at the notion of time: art is a meanwhile, it is locked in eternal return, as I have suggested, while the face is not. As Cohen points out, 'Levinas invokes the famous Jewish proscription of images, then, not as a proof text, or a thundering command from the sky, but rather to highlight two kinds

${ }^{5}$ But he doubts, for example, that Pygmalion's sculpture coming to life, or Snow White's opening of her eyes are uncanny (Freud 1955: 246). For Freud, of course, the experience of uncanny also relates to psychoanalysis: 'An uncanny experience occurs either when repressed infantile complexes have been revived by some impression, or when the primitive beliefs we have surmounted seem once more to be confirmed' (Freud 1955: 249). 
of temporalization, one the temporality of fate, closure, stasis, which Levinas will...relate to art qua aestheticism, and the other more challenging temporality of life, which comprises moral freedom, initiative, and genuine novelty' (Cohen 2016: 153). So art is not simply rejected because it substitutes idol for face, but must be approached critically because it remains 'partial', its world is self-enclosed and its temporality is a closure. In Otherwise Then Being or Beyond Essence, for example, Levinas shows how through art essence and temporality resound, that 'search for new forms, from which all art lives, keeps awake everywhere the verbs that are on the verge of lapsing into substantives', how in diversity of art works 'the essence they modulate is temporalized' (Levinas 2008: 40). But for all this the work of art does not have the temporality of life; it can and does function in isolation. At the same time, art is capable of creating the illusion that its temporality is real, as real as radical alterity. It is against this illusionary character of art that Tertullian and St. Augustine among others were already fighting. It has been said that Aphrodite of Knidos (350-300 B. C.) by Praxiteles was so lifelike it was coming to life and speaking to people. Ovid's Pygmalion falling in love with his sculpture. Or think of the reverse temporalization in Oscar Wilde's Story of Dorian Gray where the time of life and change has passed to the painting, which 'ages', leaving the living face forever young. Are not the stories of vampires, zombies and the like, stories about the lost temporality of life and the gained temporality of stasis? It may seem as if sculptures or paintings or vases look at you, but they do not. It is not even an empty look - it is no-look, not a look: 'like the gods immobilized in the between-time of art, left for all eternity on the edge of the interval, at the threshold of a future that is never produced, statues looking at one another with empty eyes, idols which $<\ldots>$ are exposed and do not see' (Levinas 2007: 221-222). Any literary artistic attempt to overcome this difference between image and the face, between two types of temporalization, leads to tales of the uncanny. Levinas makes us see the difference and sobers us up from that illusion. 'Within the life, or rather the death, of a statue, an instant endures infinitely: eternally Laocoon will be caught up in the grip of serpents; the Mona Lisa will smile eternally. Eternally the future announced in the strained muscles of Laocoon will be unable to become present. Eternally, the smile of the Mona Lisa about to broaden will not broaden' (Levinas 1987: 138). It does not mean that we have to ignore art or become iconoclasts, 'idol smashers', but rather that we must recognize the limitations of being enchanted by its Sirens' voices. Art divorced from all else becomes or is susceptible to becoming a tool of ideology or propaganda, or becomes a comic book. Closing in upon itself and distancing itself from the socio-political-economic world can be enchanting, certainly, but it can also be irresponsible and dangerous.

\section{IN LIEU OF ENDING}

For Freud the uncanny indicates that something familiar has been repressed, so that the uncanny leads us back to what is known and familiar. For Heidegger the uncanny is the ontological structure of Dasein. Different aspects of uncanniness are unveiled in the relationship of art and ethics. There is something dark and monstrous in their knot. No wonder that almost all political and religious systems have wanted to control art, to censor it or to force it to endorse a worldview.

There is always ambiguity, a certain monstrous power, a blindness of art, especially when it seems to take the place of reality, seeming to be more real than the real. For Levinas it is important to keep art in the site of ethics, to keep it engaged in the world. That would not (and should not) eliminate the monstrous, uncanny aspect of art but by keeping it engaged, art itself might preserve the very possibility of the ethical and function as a constant reminder 
of the alterity of the other. As Levinas puts the matter: 'face must not be understood in a narrow way. This possibility for the human of signifying in its uniqueness, in the humility of its nakedness and mortality, the Lordship of its recall - word of God - of my responsibility for it, and of my choosiness qua unique to this responsibility, can come from a bare arm sculpted by Rodin' (Levinas 1998: 231-232).

Some parts of this article, entitled "Face” in the Media' was presented at the conference 'Ethics in Media and Technology Environment' („Etika medijų ir technologijų aplinkose“), organized by the Lithuanian Academy of Science together with the Vilnius Gediminas Technical University Department of Philosophy and Cultural Studies, and the Lithuanian Association for Communication on 22 January 2019, and again, later, under the title 'What is Uncanny about Visualizing the Face' at an internationl conference 'Visuality 2019: Creative Communication in the Emerging Constellations', organized by Vilnius Gediminas Technical University Faculty of Creative Industries, Lithuania, on 25 April 2019.

Received 20 May 2019

Accepted 29 August 2019

\section{References}

1. Asma, S. T. 2009. On Monsters: an Unnatural History of Our Worst Fears. Oxford, New York: Oxford University Press.

2. Baltrušaitis, J. 1955. Le Moyen Age fantastique: antiquités et exotismes dans lart gothique. Paris: Armand Colin.

3. Beal, T. K. 2002. Religion and its Monsters. New York: Routledge.

4. Cohen, R. A. 2010. Levinasian Meditations: Ethics, Philosophy, and Religion. Pittsburgh: Duquesne University Press.

5. Cohen, R. A. 2016. 'Levinas on Art and Aestheticism. Getting "Reality and Its Shadow" Right', Levinas Studies 11: 149-194.

6. Eaglestone, R. 1997. Ethical Criticism: Reading after Levinas. Edinburgh: Edinburgh University Press.

7. Eco, U. 2007. On Ugliness. New York: Rizzoli.

8. Ellison, D. R. 2001. Ethics and Aesthetics in European Modernist Literature: from the Sublime to the Uncanny. Cambridge, New York: Cambridge University Press.

9. Foucault, M. 2003. Abnormal: Lectures at the Collège de France, 1974-1975. New York: Picador.

10. Freud, S. 1955. 'The Uncanny', in The Standard Edition of the Complete Psychological Works of Sigmund Freud. London: The Hogarth Press.

11. Freud, S. 1997. Writings on Art and Literature. Stanford: Stanford University Press.

12. Kearney, R. 2003. Strangers, Gods, and Monsters: Interpreting Otherness. London, New York: Routledge.

13. Levinas, E. 1987. Collected Philosophical Papers. Transl. A. Lingis. Dordrecht, Netherlands; Boston: Martinus Nijhoff.

14. Levinas, E. 1989. 'Reality and its Shadow', in The Levinas Reader, ed. S. Hand. Oxford, UK: Blackwell.

15. Levinas, E. 1990. Difficult Freedom: Essays on Judaism. Transl. S. Hand. Baltimore: Johns Hopkins University Press.

16. Levinas, E. 1996. 'Is Ontology Fundamental?', in Basic Philosophical Writings, eds. A. T. Peperzak, S. Critchley, R. Bernasconi. Bloomington: Indiana University Press.

17. Levinas, E. 1998. Entre Nous: On Thinking-of-the-Other. Transl. M. B. Smith. New York: Columbia University Press.

18. Levinas, E. 2003. Humanism of the Other. Transl. N. Poller. Urbana-Chicago: University of Illinois Press.

19. Levinas, E. 2007. Totality and Infinity: an Essay on Exteriority. Transl. A. Lingis. Pittsburgh: Duquesne University Press.

20. Levinas, E. 2008. Otherwise than Being or Beyond Essence. Transl. A. Lingis. Pittsburgh: Duquesne University Press.

21. Poe, E. A. 2016. 'Oval Portrait', in The Works of Edgar Allan Poe. Project Gutenberg.

22. Robbins, J. 1999. Altered Reading: Levinas and Literature. Chicago: University of Chicago Press. 
JOLANTA SALDUKAITYTÉ

\section{Slèpiningumo akivaizdoje: meno prasmès paieškos su E. Levinu}

\section{Santrauka}

Svarstoma, kad mene - ypač reprezentuojant veidą - glūdi monstriškumo ir nežmogiškumo elementas. Parodoma, kad iš E. Levino perspektyvos menas, suteikdamas veidui plastinę formą, pirma, ji ịkalina bei neišvengiamai paverčia karikatūra. Antra, veidas meninejje formoje praranda laikiškumą. Tai, kas gyvybinga, išraiškinga, yra sulaikyta, nesikeičia, yra nepažeidžiama ir todèl nèra etinis Kito veidas.

Straipsnyje laikomasi nuomonès, kad E. Levinas kritikuoja ne tiek meną, kiek estetizavimą. Meno prasmè iš naujo atrandama grąžinant ji i i platesni pasaulio kontekstą - socialinį, kultūrinị, politini, o visų pirma - etinị.

Raktažodžiai: menas, veidas, slèpiningumas, etika, Levinas 